\title{
Conduction disturbances after surgical closure of ventricular septal defect
}

\author{
Galal M. Ziady, K. A. Hallidie-Smith, and J. F. Goodwin
}

From the Department of Medicine (Clinical Cardiology), Royal Postgraduate Medical School and Hammersmith Hospital, London

The electrocardiograms of 208 patients with isolated ventricular septal defect or the tetralogy of Fallot who were operated upon for complete correction between 1965 and 1971 were studied preand postoperatively. Complete right bundle-branch block after closure of ventricular septal defect was common (49\%), and evidence is produced which suggests that it is probably the result of the : ventriculotomy rather than direct trauma to the right bundle. Right bundle-branch block with left anterior hemiblock was less common ( $\mathrm{I} I \%)$. Right bundle-branch block with left anterior hemiblock, especially if associated with a prolonged PR interval (trifascicular block), may predispose to complete atrioventricular block. Postoperative complete atrioventricular block is now rare $(3.8 \%)$, but predisposes to late sudden death which occurred in 4 patients in this series.

functional rhythm and junctional tachycardia are not uncommon after closure of ventricular septal defect $(23 \%)$, but these are transient and self limiting.

The possible mechanisms of the various conduction disturbances are discussed.

Much has been written on the electrocardiographic abnormalities after surgical closure of ventricular septal defect, and conduction disturbances in the form of atrioventricular block and right bundle-branch block have been described. Recently we (Kulbertus, Coyne, and Hallidie-Smith, 1969) and Rosenbaum et al. (1970) reported the development of right bundle-branch block with left anterior hemiblock in relation to closure of ventricular septal defect.

We review in this paper the conduction disturbances that occurred after surgical closure of ventricular septal defect and total correction of the tetralogy of Fallot in the last 6 years. These conduction disturbances are discussed in relation to their possible mechanisms, and to their late postoperative complications. Attention is drawn to the danger of late postoperative death due to these conduction defects.

\section{Patients and methods}

The present series consists of 208 patients with ventricular septal defect either as the sole congenital anomaly or as a part of the tetralogy of Fallot, who were investigated and operated upon in Hammersmith Hospital from 1965-1971. There were 68 patients with ventricular septal defect only, 4I male and 27 female, and 140 patients with tetralogy of Fallot, 77 male and 63 female (Table I). Their age distribution at the time of the operation is shown in Table 2, the youngest being 2 years and the oldest 48 years. The electrocardiograms of all these patients were analysed preoperatively, with serial electrocardiograms immediately postoperatively in all 208, and for up to 5 years after operation in 39 patients. The electrocardiograms were analysed for the presence of arrhythmias (abnormalities in impulse formation) and for conduction disturbances in the form of right bundle-branch block, left anterior hemiblock, and atrioventricular block. An example of the conduction disturbances in one case is shown in Fig. I. Right bundle-branch block was diagnosed when the QRS duration was more than 0.12 sec and when the intrinsicoid deflection was delayed in the right praecordial leads to $0.09 \mathrm{sec}$ or more. Left anterior hemiblock was diagnosed when the mean frontal QRS axis was more than $-30^{\circ}$ with qI, SIII pattern (Rosenbaum, 1969) (Fig. 2 and 3).

TABLE I Number of patients available for study

\begin{tabular}{lrll}
\hline & & Male & Female \\
\hline Ventricular septal defect & 68 & 41 & 27 \\
Tetralogy & 140 & 77 & 63 \\
\hline Total & 208 & I 18 & 90 \\
\hline
\end{tabular}


The postoperative serial electrocardiograms were also analysed for intermittent conduction disturbances and/or transient arrhythmias.

\section{Results}

Of the 208 patients, I02 developed right bundle-branch block after operation, 25 of 68 after closure of simple ventricular septal defect $(31 \cdot 7 \%)$ and 77 of $140(55 \%)$ after total correction of the tetralogy of Fallot. While a total of 102 patients out of $208(49 \%)$ developed lone right bundle-branch block, 22 of them (II\%) developed right bundlebranch block with left anterior hemiblock.

Eight patients developed atrioventricular block $(3.3 \%), 5$ patients with the tetralogy of Fallot and 3 with ventricular septal defect. In 4 of them there was persistent complete atrioventricular block. One of these developed acute complete trifascicular block (distal type of block), which recovered a few days postoperatively, but the patient was followed for 4 years in atrioventricular block alternating with sinus rhythm. Twenty-seven patients (13\%) developed junctional rhythm after operation. Twenty-one patients (10\%) developed supraventricular tachyarrhythmias mainly in the form of junctional tachycardia. These arrhythmias lasted for a short period after operation and recovered with or without treatment, but with a tendency for late postoperative recurrence.

One patient developed atrial flutter, and 2 patients developed atrial fibrillation, but only one patient had persistent atrial fibrillation. This was a female patient who had her ventricular septal defect and her tricuspid valve repaired at the age of 48 years.

Four late postoperative deaths (14 months up to 3 years postoperatively) occurred among this series. Three of these patients developed right bundle-branch block with left anterior hemiblock postoperatively. The fourth developed right bundle-branch block alone with strong right axis deviation $+130^{\circ}$. Necropsy did not reveal any anatomical cause for death, suggesting the possibility of acute fatal

FIG. I Three electrocardiograms of a girl aged I 3 years. $(A)$ Before operation: right axis deviation with right ventricular hypertrophy. (B) Three days after operation: the development of complete atrioventricular block with external pacemaker. (C) Two weeks after operation: complete right bundle-branch block, left anterior hemiblock, and first-degree atrioventricular block (trifascicular block). arrhythmia in the form of asystole or veniricular fibrillation as the cause. One of these patients, who had a ventricular septal defect with mild infundibular hypertrophy, developed right bundle-branch block with left

(A)
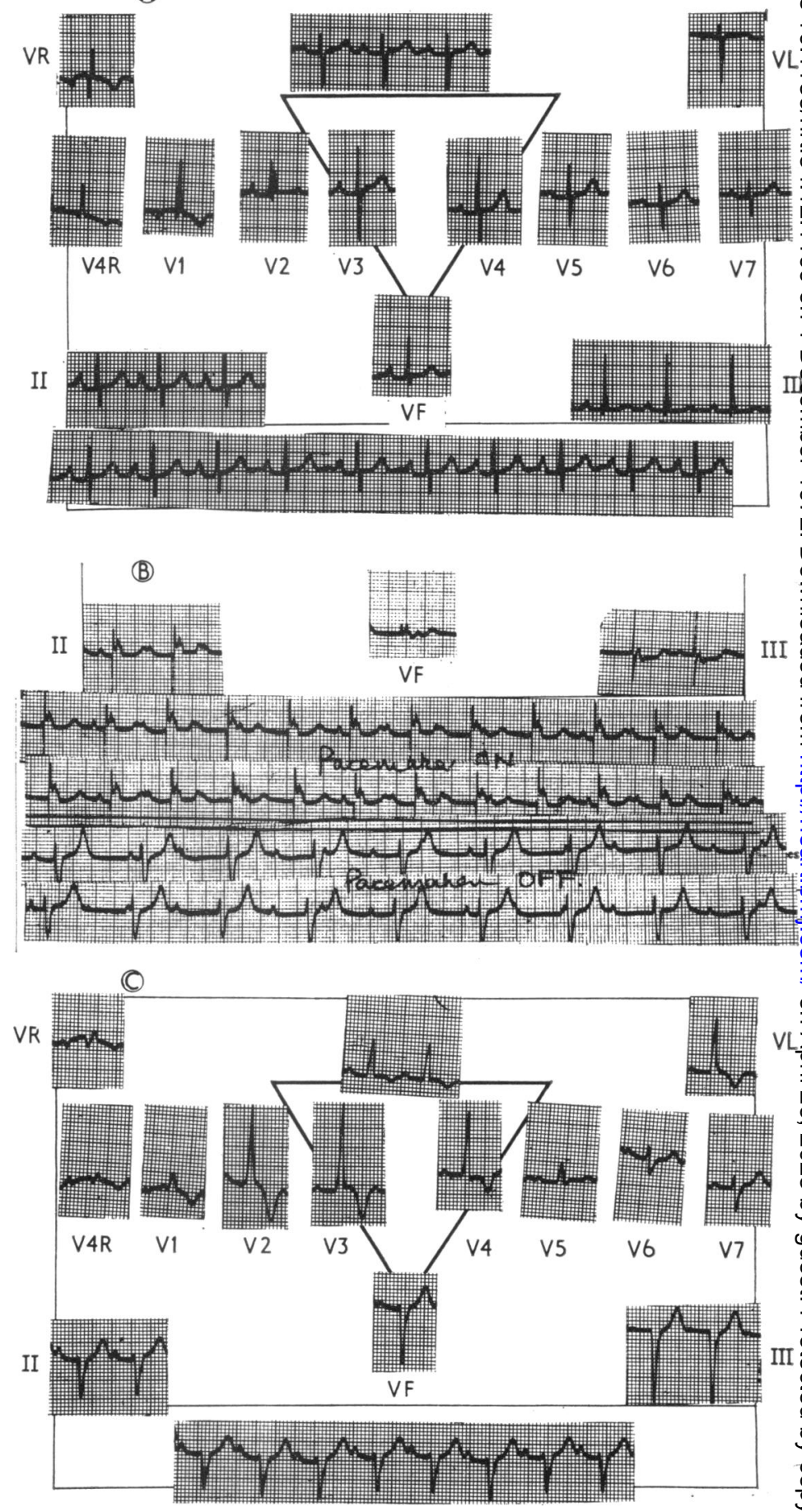
anterior hemiblock and various forms of tachyarrhythmias in the form of junctional tachycardia, atrial flutter, and ventricular tachycardia (Fig. 4). These arrhythmias were recurrent and the patient was readmitted to the hospital on many occasions for DC conversion. Eventually he died in the dental chair after receiving nitrous oxide anaesthesia for dental extraction and again necropsy did not reveal any anatomical cause for his death, which was probably due to the development of an arrhythmia or complete heart block. These results are shown in Table 3.

\section{Discussion}

The bundle of His is closely related to the posteroinferior angle of the ventricular septal defect, whereas the right bundle, which is the direct continuation of the main bundle, is slightly anterior to it along the inferior edge of the defect. The anterior division of the left and hence related to the inferior border of the defect. Thus it is the site of the defect rather than its size that determines the relation to the conducting tissues.

The incidence of operative atrioventricular block in our own experience has decreased considerably in recent years, as others have found (Lawer et al., 1960; Titus et al., 1963; Lillehei et al., 1963; Lev et al., 1964; Cartmill et al., 1966). This reduction is mainly the result of more precise recognition of the anatomy of the conduction tissue in ventricular septal defect and tetralogy of Fallot and of increasing surgical experience. Lawer et al. (1960) reported the incidence of complete atrioventricular block after repair of ventricular septal defect to be 19 per cent. In this series, the incidence of complete heart block was 3.8 per cent.

Recently Fryda, Kaplan, and Helmsworth (I97I) reported the incidence of surgical AV bundle is closely related to the right bundle

TABLE 2 Age distribution of patients studied

\begin{tabular}{lccll}
\hline & $\begin{array}{l}\text { Children } \\
(2-16 \text { yr })\end{array}$ & $\begin{array}{l}\text { Mean age of } \\
\text { children }(y r)\end{array}$ & $\begin{array}{l}\text { Adults } \\
(17-48 \text { yr })\end{array}$ & $\begin{array}{l}\text { Mean age of } \\
\text { adults }(y r)\end{array}$ \\
\hline Ventricular septal defect & 55 & 8 & 13 & 30 \\
Tetralogy & 112 & 10.3 & 28 & 23.3 \\
\hline
\end{tabular}

block in children with congenital heart disease to be 4 per cent. The early cases reported developed the proximal type of atrioventricular block as a result of damage to the atrioventricular node. Complete atrioventricular block can also arise distal to the bundle of His and be due to trifascicular or bilateral bundlebranch block, through interruption of the pathway in the right bundle-branch associated with block of the left anterior or left posterior branch of the left bundle, either permanently or intermittently (Scherlis and Lee, I96I; Reemtsma, Delgado, and Creech, 1960;

FIG. 2 The range of the mean frontal plane $Q R S$ axis before and after operation in 22 patients who developed right bundle-branch block with left anterior hemiblock postoperatively.
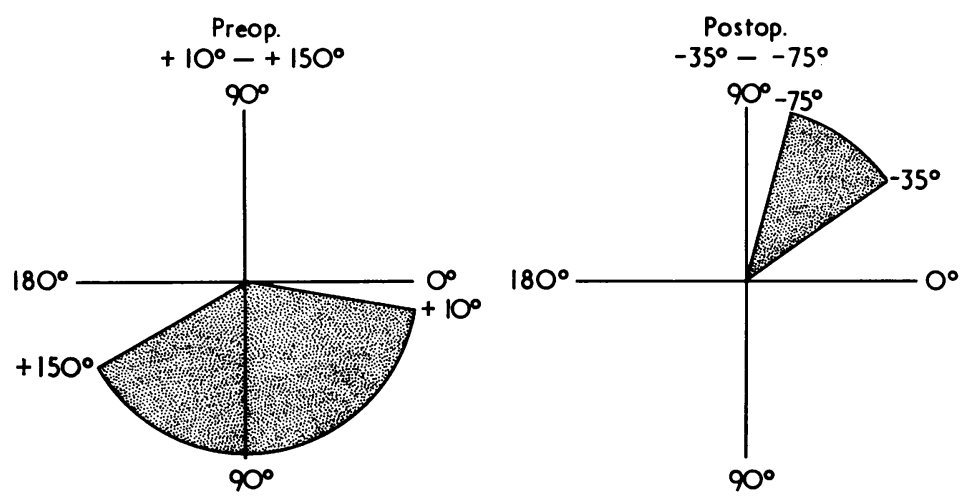

TABLE 3 Acquired electrocardiographic abnormalities postoperatively

\begin{tabular}{|c|c|c|c|c|c|c|}
\hline & \multicolumn{3}{|c|}{ Conduction disturbances } & \multicolumn{3}{|c|}{ Arrhythmias } \\
\hline & $\begin{array}{l}\text { Right bundle- } \\
\text { branch block }\end{array}$ & $\begin{array}{l}\text { Right bundle- } \\
\text { branch block } \\
\text { with left } \\
\text { anterior block }\end{array}$ & $\begin{array}{l}\text { AV } \\
\text { block }\end{array}$ & $\begin{array}{l}\text { functional } \\
\text { rhythm }\end{array}$ & $\begin{array}{l}\text { Supra- } \\
\text { ventricular } \\
\text { tachycardia }\end{array}$ & $\begin{array}{l}\text { Atrial } \\
\text { fibrillation } \\
\text { and flutter }\end{array}$ \\
\hline $\begin{array}{l}\text { Ventricular septal defect: } \\
68 \text { cases }\end{array}$ & $\begin{array}{l}25 \\
37 \%\end{array}$ & 10 & 3 & 16 & I I & 2 \\
\hline $\begin{array}{l}\text { Tetralogy: } \\
\text { I40 cases }\end{array}$ & $\begin{array}{l}77 \\
55 \%\end{array}$ & 12 & 5 & I I & 10 & $\mathbf{I}$ \\
\hline $\begin{array}{l}\text { Total: } \\
208 \text { cases }\end{array}$ & $\begin{array}{l}102 \\
49 \%\end{array}$ & $\begin{array}{l}22 \\
11 \%\end{array}$ & $\begin{array}{l}8 \\
3 \cdot 8 \%\end{array}$ & $\begin{array}{l}27 \\
13 \%\end{array}$ & $\begin{array}{l}21 \\
10 \%\end{array}$ & $\begin{array}{l}3 \\
1 \cdot 5 \%\end{array}$ \\
\hline
\end{tabular}


Rosenbaum et al., 1970; Potter, Liu, and Maynard, 1971).

Though the development of atrioventricular block is not now a problem, the development of right bundle-branch block after surgical closure of ventricular septal defect is still common ( $49 \%$ in this series).

Though Bristow et al. (1960), Lev et al., (1964), and Kulbertus et al. (1969) related the development of right bundle-branch block to direct trauma of the right bundle during repair of the defect, we now believe that this is not the sole mechanism. The early reports in $1960^{\circ}$ related the development of right bundle-branch block to direct trauma to the bundle, because of the frequent occurrence of complete heart block. But now the anatomy is well recognized by the surgeon, who avoids the atrioventricular bundle and the right bundle-branch. Furthermore, most ventricular septal defects are closed by a patch which is larger in size than the septal defect itself. Since stitches are placed, therefore, at some distance from the margins of the defect, the large oblique ventriculotomy incision in the outflow tract of the right ventricle rather than the patching sutures may be the cause of development of complete right bundle-branch block. Ventriculotomy for infundibular resection and for pulmonary valvotomy without interference with the ventricular septum may produce complete right bundle-branch block. Kittle, Santos, and Dimond (1956) reported 4 of 3 I patients, and we have encountered 2 patients in whom persistent right bundlebranch block occurred after infundibular resection for pulmonary stenosis.

Coggin, Wareham, and Selvester (1960) reported the development of right bundlebranch block after right ventriculotomy in 45 patients. Right bundle-branch block developed when the right ventricle was incised, the septum being undisturbed. These findings were confirmed in healthy dogs under extracorporeal circulation. A ventriculotomy was performed and the septum left untouched. In all the dogs right bundle-branch block developed when the right ventricle was incised. The pathogenesis of right bundle-branch block after ventriculotomy is not clear, but it may be explained by a peripheral type of block in the ventricular wall itself rather than in the main right bundle. Also, it is evident from the results that right bundle-branch block after total correction of the tetralogy of Fallot is more common than after repair of simple ventricular septal defect, and it is also more common in cases of ventricular septal defect with raised pulmonary vascular resistance, and hence more right ventricular hypertrophy.

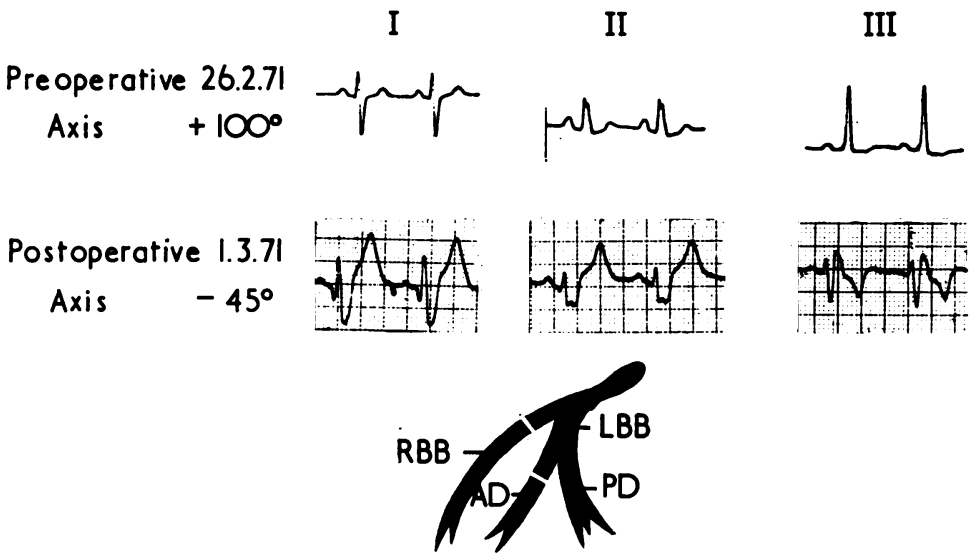

FIG. 3 The standard electrocardiographic leads of a boy aged II years before and after operation, who developed right bundle-branch block with left anterior hemiblock postoperatively, with a diagrammatic representation of the division of the His bundle and its right and left bundle-branch. $R B B$, Right bundlebranch; $L B B$, left bundle-branch; $A D$, anterior division of left bundle; $P D$, posterior division of left bundle.

FIG. 4 Postoperative electrocardiogram of a boy aged II years with supraventricular tachycardia with aberrant conduction and the effect of intravenous injection of $2 \mathrm{mg}$ propranolol in reverting it to junctional rhythm. This patient was among the late postoperative deaths due to arrhythmias.

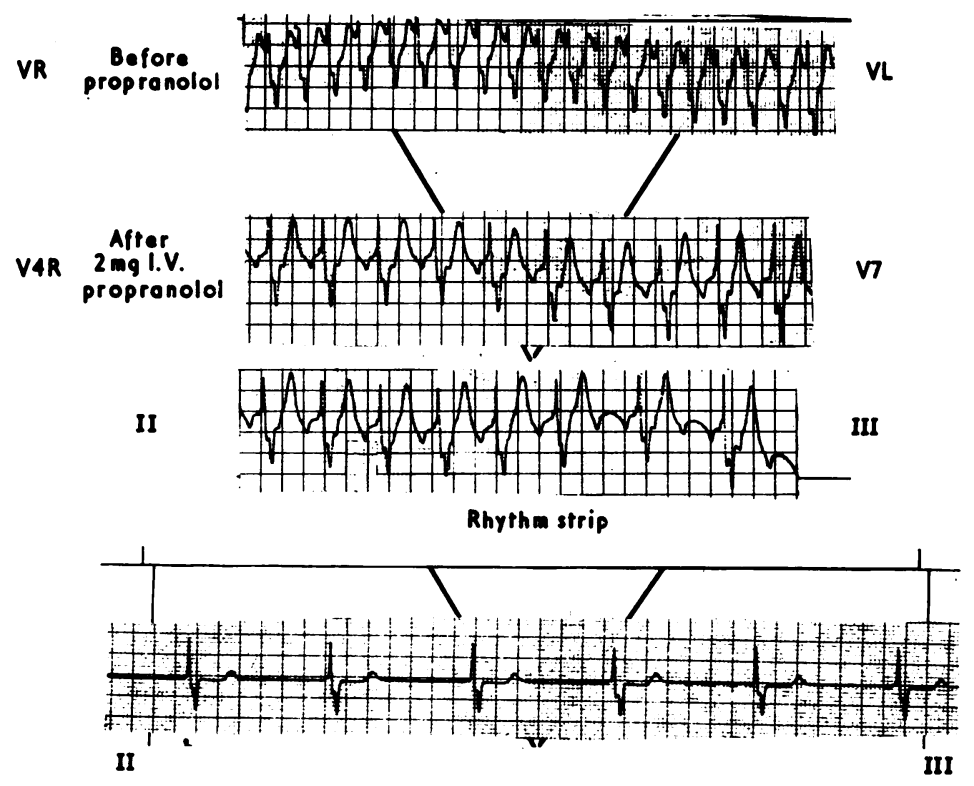


The development of left anterior hemiblock in association with right bundle-branch block occurred in I I per cent of our patients. Many authors have reported the development of this conduction disturbance in ischaemic heart disease and sclerosis of the cardiac skeleton (Rosenbaum and Lepeschkin, 1955; Lepeschkin, 1964; Schamroth and Bradlow, 1964; Lenegre, 1966; Saltzman, Linn, and Pick, 1966; Watt et al., 1968). The first report of right bundle-branch block with left anterior hemiblock in relation to surgical correction of the tetralogy of Fallot was by Rosenbaum (1969), who reported 2 of 40 patients with the tetralogy of Fallot whose electrocardiograms were transformed into a pattern simulating that seen in common atrioventricular canal. Kulbertus et al. (1969) reported 7 patients who developed this disturbance after surgical correction, and this was followed by a further report by Rosenbaum (1970) describing 5 cases of tetralogy who developed right bundlebranch block with left anterior hemiblock after total correction.

The cause of this abnormality after closure of ventricular septal defect may be actual anatomical interruption of the fibres of the anterior division of the left bundle during closure of the septal defect, which has a direct anatomical relation to the conducting tissue.

The observations by Takayasu et al. (1962), Hushaw and Linde (1965), Lasser, Haft, and Friedberg (1968), Kulbertus et al. (1969), and by ourselves suggest that the development of complete right bundle-branch block with left anterior hemiblock or right and left bundle-branch block (bilateral bundle-branch block), especially if associated with firstdegree heart block, constitutes a potential hazard for the development of complete atrioventricular block. Potter et al. (1971) reported a patient followed for 18 months after total correction of the tetralogy of Fallot, who developed complete atrioventricular block after operation, and alternated between sinus rhythm and complete atrioventricular block. We have encountered 3 patients of this type in whom complete atrioventricular block occurred in addition to right bundle-branch block and left anterior hemiblock spontaneously late postoperatively. This contrasts with the experience of Murphy et al. (1970), who believe that $\mathrm{AV}$ dissociation in children after open heart surgery is benign.

Cartmill et al. (1966) reported 6 late deaths, 2 with heart block and I with paroxysmal tachycardia after cardiac catheterization after surgical closure of ventricular septal defect, and three other sudden deaths. Four of our patients died after operation and no anatomi- cal cause for their death was discovered at necropsy. We consider that the association of right bundle-branch block with left anterior hemiblock, and either evidence of disturbance of conduction in the remaining fascicle (such as a long PR interval), or syncopal attacks, is an indication for a demand pacemaker.

Other arrhythmias that occur after closure of ventricular septal defect in the form of junctional rhythm and junctional tachycardia are all related to oedema, haemorrhage, and/or hypoxia around the junctional tissue (Cartmill et al., 1966; Thung et al., 1967). These are transient and disappear with or without specific treatment, and have no relation to other conduction disturbances, though patients with intermittent left and right bundlebranch block tend to develop paroxysmal tachycardia.

\section{References}

Bristow, J. D., Kassebaum, D. G., Starr, A., and Griswold, H. E. (1960). Observations on the occurrence of right bundle-branch block following open repair of ventricular septal defects. Circulation, 22, 896.

Cartmill, T. B., Dushane, J. W., McGoon, D. C., and Kirklin, J. W. (1966). Results of repair of ventricular septal defect. Fournal of Thoracic and Cardiovascular Surgery, 52, 486.

Coggin, C. J., Wareham, E. E., and Selvester, R. H. (1960). Postventriculotomy right bundle-branch block: its etiology. Abstract of the 33rd Scientific Sessions of the American Heart Association. Circulation, 22, 734.

Fryda, R. J., Kaplan, S., and Helmsworth, J. A. (197I). Postoperative complete heart block in children. British Heart fournal, 33, 456.

Hushaw, J. R., and Linde, L. M. (1965). Alternating bundle branch block following heart surgery. Fournal of Pediatrics, 67, 494.

Kittle, C. F. Santos, E. M., and Dimond, E. G. (1956). Persistent right bundle branch block due to pulmonic valvotomy and infundibulectomy. American Surgeon, 22, 80.

Kulbertus, H. E., Coyne, J. J., and Hallidie-Smith, K. A. (1969). Conduction disturbances before and after surgical closure of ventricular septal defect. American Heart fournal, 77, 123.

Lasser, R. P., Haft, J. I., and Friedberg, C. K. (1968). Relationship of right bundle-branch block and marked left axis deviation (with left parietal or periinfarction block) to complete heart block and syncope. Circulation, 37, 429.

Lawer, R. M., Ongley, P. A., DuShane, J. W., and Kirklin, J. W. (I960). Heart block after repair of ventricular septal defect in children. Circulation, 22, 526.

Lenegre, J. (1966). Bilateral bundle branch block. Cardiologia, 48, 134.

Lepeschkin, E. (1964). The electrocardiographic diagnosis of bilateral bundle branch block in relation to heart block. Progress in Cardiovascular Diseases, 6, 445.

Lev, M., Fell, E. H., Arcilla, R., and Weinberg, M. H. (1964). Surgical injury to the conduction system in ventricular septal defect. American fournal of Cardiology, 14, 464 . 
Lillehei, C. W., Sellers, R. D., Bonnabeau, R. C., and Elliot, R. S. (1963). Chronic postsurgical complete heart block. Fournal of Thoracic and Cardiovascular Surgery, 46, 436.

Murphy, D. A., Tynan, M., Graham, G. R., and Bonham-Carter, R. E. (1970). Prognosis of complete atrioventricular dissociation in children after openheart surgery. Lancet, $\mathbf{I}, 750$.

Potter, R. T., Liu, L., and Maynard, E. P. (197I). Post-surgical heart block. Report of a case with bilateral bundle-branch block and changing rhythms. British Heart fournal, 33, 412.

Reemtsma, K., Delgado, J. P., and Creech, O. (1960). Heart block following intracardiac surgery: localisation of conduction tissue injury. Fournal of Thoracic and Cardiovascular Surgery, 39, 688.

Rosenbaum, M. B. (1969). Types of left bundle branch block and their clinical significance. Fournal of Electrocardiography, 2, 197.

Rosenbaum, M. B. (I970). The hemiblocks: diagnostic criteria and clinical significance. Modern Concepts of Cardiovascular Disease, 39, I4I.

Rosenbaum, M. B., Corrado, G., Oliveri, R., Castellanos, A., Jr., and Elizari, M. K. (1970). Right bundle branch block with left anterior hemiblock surgically induced in tetralogy of Fallot. American fournal of Cardiology, 26, 12.

Rosenbaum, M. B., and Lepeschkin, E. (1955). Bilateral bundle branch block. American Heart fournal, 50, 38.

Saltzman, P., Linn, H., and Pick, A. (1966). Right bundle-branch block with left axis deviation. British Heart fournal, 28, 703.
Schamroth, L., and Bradlow, B. A. (1964). Incomplete left bundle-branch block. British Heart fournal, 26, 285.

Scherlis, L., and Lee, Y. C. (196I). Right bundle branch block following open heart surgery. Electrocardiographic and vectorcardiographic study. American fournal of Cardiology, 8, 780.

Takayasu, M., Tateishi, Y., Kato, S., Inoue, Y., Morishima, T., and Hattori, K. (I962). Alternating right and left bundle branch block pattern and $A-V$ block of various degrees with Stokes-Adams syndrome. Fapanese Heart fournal, 3, 494.

Thung, N., Dammann, J. F., Diaz-Perez, R., Thompson, W. M., Sanmarco, M., and Mehegan, C. (1967). Hypoxia as the cause of haemorrhage into the cardiac conduction system, arrhythmia and sudden death. Fournal of Thoracic and Cardiovascular Surgery, 44, 687.

Titus, J. L., Daugherty, G. W., Kirklin, J. W., and Edwards, J. E. (1963). Lesions of the atrioventricular conduction system after repair of ventricular septal defect - relation to heart block. Circulation, $28,82$.

Watt, T. B., Jr., Freud, G. E., Durrer, D., and Pruitt, R. D. (I968). Left anterior arborization block combined with right bundle branch block in canine and primate hearts: an electrocardiographic study. Circulation Research, 22, 57.

Requests for reprints to Professor J. F. Goodwin, Department of Medicine (Clinical Cardiology), Royal Postgraduate Medical School, Hammersmith Hospital, London W.I2. 